\title{
FENOMENA HOAX: Tantangan terhadap Idealisme Media \& Etika Bermedia
}

\author{
Fabianus Fensi \\ IImu Komunikasi, Universitas Bunda Mulia \\ Disetujui 5 September 2018
}

\begin{abstract}
The hoax phenomenon is a historical reality. He was born along with the birth of the era of information media freedom. Hoaxes are often damaging to a pluralistic society. History records that hoaxes destabilize harmony of a society. Therefore the hoax must be terminated immediately. This paper uses a textual literature study approach. Hoax phenomenon is placed in the tension between media idealism and media ethics. The scope of the discussion began with a review of some of the country's formal regulations, such as the Law that had been produced. For the author, state regulation of media life is an ideal condition (media idealism) where the state is based on its capacity to regulate what must be broadcast. The result is that ideal conditions do not always have an impact in reality. Many rules are violated in the practice of media, especially social media. So, there should be room to be filled in to overcome this gap, namely an ethical commitment as a normative necessity for social media activists. Law enforcement alone is not enough so it must also be equipped with other social capital, namely: the firmness of citizens' attitudes, are social media users to maintain the integrity of society. The integrity is possible by the determination of the social media community to ensure a truth of the message before it is broadcast to the public; Maintain the privileges inherent in each individual; Strictly separating the realm of private issues from public problems; Reveal a message that avoids lying, slander, and attacking others' personal motives; and full awareness that the cultural diversity of society is sensitive. All of these are referred to as ethical principles that must be considered as guidelines for living together as a nation.
\end{abstract}

Keywords: Ethics, Hoaxes, Social Media, Plurality, Regulation.

\begin{abstract}
ABSTRAK
Fenomena hoax adalah sebuah kenyataan sejarah. Dia lahir bersamaan dengan kelahiran era kebebasan media informasi. Namun, keberadaannya seringkali merusak tatanan masyarakat yang plural. Sejarah mencatat bahwa hoax menggoyahkan kerukunan, bahkan perpecahan masyarakat. Karena itu hoax harus segera diakhiri. Tulisan ini menggunakan pendekatan kajian literatur tekstual, dimana fenomena hoax ditempatkan dalam ketegangan antara idealisme media dan etika bermedia. Cakupan pembahasan dimulai dari tinjauan terhadap beberapa regulasi formal negara, seperti Undang-undang yang pernah dihasilkan. Bagi penulis, regulasi negara atas kehidupan media adalah kondisi ideal (idealisme media) dimana negara berdasarkan kapasitasnya mengatur apa yang harus disiarkan. Hasilnya bahwa kondisi ideal tidak selalu berdampak dalam kenyataannya. Banyak aturan dilanggar dalam praktik bermedia, terutama media sosial. Maka, seharusnya ada ruang yang harus diisi untuk mengatasi kesenjangan tersebut, yaitu sebuah komitmen etis sebagai keharusan normatif bagi para pegiat media sosial. Penegakan hukum saja tidak cukup maka harus pula dilengkapi modal sosial yang lain, yaitu: keteguhan sikap warga negara, pengguna media sosial untuk menjaga keutuhan masyarakat. Keutuhan itu dimungkinan oleh keteguhan masyarakat media sosial untuk memastikan sebuah kebenaran pesan sebelum disiarkan kepada publik; Menjaga hak istimewa yang melekat pada setiap individu; Memisahkan dengan tegas ranah persoalan privat dari persoalan publik; Mengungkapkan pesan yang menghindari motif-motif bohong, fitnah, dan menyerang pribadi orang lain; dan kesadaran penuh bahwa keragaman budaya masyarakat adalah sensitif. Semua ini disebut sebagai prinsip etis yang harus dianggap sebagai pedoman hidup bersama sebagai bangsa.
\end{abstract}

Kata Kunci: Etika, Hoax, Media Sosial, Pluralitas, Regulasi. 


\section{PENDAHULUAN}

Kebebasan bermedia adalah satu hal sementara fenomena hoax adalah hal lainnya. Pertanyaannya, apakah kebebasan bermedia bisa menjadi ruang bagi berkembangnya hoax, ataukah hoax itu sesuatu yang berdiri sendiri yang tidak memiliki kaitan dengan kebebasan bermedia? Kalau saja jawabannya kebebasan melahirkan hoax, lalu apa artinya sebuah kebebasan itu sendiri? Atau, kalau hoax sesuatu yang tidak memiliki kaitan dengan kebebasan bermedia lalu mengapa fenomena hoax itu justru mengalami momentum kebangkitannya dalam sebuah era information surplus?

Masyarakat kita dikesankan "seolah-olah" sedang berbulan madu dengan apa yang disebut sebagai kebebasan dengan rupa-rupa perangkat media digital yang dimiliki.

Penelitian ini didorong oleh sebuah dilemma keprihatinan, di satu pihak masyarakat sedang menikmati fajar baru kebebasan berekspresinya. Atas nama demokrasi kebebasan diagungkan sebagai mahkota ekspresi hak asasi manusia untuk menyampaikan pendapat. Masyarakat kita paling gampang memanfaatkan media, apa pun, untuk menyatakan sesuatu, baik yang menyangkut kesukaan pun apa yang tidak disukainya.

Namun, di lain pihak era ini menandakan sebuah degradasi nilai karena terjadi benturan antara tradisi "bertanggung jawab" atas ekspresi diri dengan keinginan "reaksioner" untuk melampiaskan apa saja yang sedang dialami kini.

Penelitian ini berusaha mencari ruang kesenjangan yang perlu diisi di antara ruang ideal sebuah kebebasan dengan ruang bergelimangnya hoax dalam sebuah struktur masyarakat plural seperti Indonesia. Saya menggunakan terminologi plural dalam pengertian yang luas, yaitu kondisi masyarakat Indonesia yang tidak bisa

\footnotetext{
*Korespondensi Penulis:

E-mail: fabianusfensi@gmail.com
}

menolak begitu saja kenyataan keberagaman sebagai keterberian sejarah (historical given). Sejarah Indonesia adalah pluralitas dan pluralitas itu sendiri sudah menjadi historical being untuk Indonesia.

Keberagaman, entah suku, ras, agama, dan golongan sudah ada jauh sebelum ada generasi baru yang kita sebut sebagai generasi milenial. Suatu generasi yang peradabannya begitu mudah memanfaatkan aspek freedom, tidak sekadar sebagai tempat memperlihatkan eksistensi diri di tengah dunia yang kompleks, tetapi lebih dari itu, kini freedom sudah menjadi gaya hidup baru.

$\begin{array}{ccc}\text { Berbagai media sosial digital } \\ \text { menawarkan } & \text { kemudahan } & \text { bagi }\end{array}$ penggunanya. Akhirnya, gawai dalam genggaman itu berhasil mengendalikan gaya hidup orang (cara berpakaian, cara berperilaku, dan cara bertutur kata). Semua dikendalikan secara digital.

Hoax pun menjadi gaya hidup. Kebenaran diputarbalikan. Kemudian banyak pengamat menyebut fenomena ini sebagai post-truth. Kebenaran termuat didalam ketidakbenaran, dan ketidakbenaran itulah kebenaran. Atau, hoax adalah kebenaran, lalu kebenaran dianggap sebagai hoax. Fenomena semacam ini tentu menakutkan.

Kelompok masyarakat yang menamakan dirinya "Masyarakat Telematika Indonesia (Mastel) ${ }^{\prime \prime 19}$ mengkuatirkan wabah hoax di

\footnotetext{
${ }^{19}$ Dikutip dari laman www.mastel.id, MASTEL adalah sebuah lembaga nirlaba yang didirikan tanggal 1 Desember 1993. MASTEL adalah sebuah wadah bagi seluruh pemangku kepentingan di bidang Teknologi Informasi, Komunikasi dan Penyiaran, yang terdiri dari pelaku usaha, organisasi, asosiasi dan profesional. Saat ini MASTEL didukung oleh 26 Asosiasi, 101 Perusahaan (Donatur dan Reguler), 871 Anggota perorangan, 21 Organisasi Nirlaba. MASTEL sudah memiliki anggota dari lintas industri, profesi dan komunitas. Kemitraan dan kolaborasi strategis yang dibangun MASTEL diantaranya kepada Pemerintah, Dewan Perwakilan Rakyat, Kedutaan Besar Negara-Negara Sahabat. Pemerintah. MASTEL secara intens menjalin kemitraan kerja dengan Pemerintah diantaranya Kementerian KOMINFO RI, Kementerian Perdagangan, BAPPENAS, Kementerian Perindustrian,
} 
Indonesia akan berdampak langsung pada perpecahan bangsa, instabilitas politik, dan berbagai gangguan keamanan lainnya yang bisa saja berpotensi menghambat proses pembangunan secara nasional.

Asumsi ini diperkuat melalui hasil survei $^{20}$ yang pernah dilakukan lembaga ini. Hasil survei menunjukkan bahwa $75.90 \%$ masyarakat kita menganggap hoax mengganggu kerukunan masyarakat dan $70.20 \%$ hoax bisa menghambat pembangunan yang sedang berjalan.

Dan, dari survei yang sama diketahui bahwa ada dua bidang dalam kehidupan sosial masyarakat yang paling rentan dieksploitasi fenomena hoax, yaitu bidang politik dan SARA. Apa yang terjadi kalau hoax politik mencapai $91.80 \%$ diterima masyarakat setiap harinya? Begitu pula, apa yang terjadi kalau setiap hari masyarakat kita disuguhi $88.60 \%$ berita hoax bermuatan SARA?

Menariknya hoax yang paling banyak diterima adalah lewat tulisan $(62.10 \%)$. Media paling dominan dipakai menyebarkan hoax adalah media sosial, seperti: facebook, twitter, instagram, dan path. Coba bayangkan $92.40 \%$ hoax disebarkan lewat media sosial. Media yang tidak kalah fenomenal dalam penyebaran hoax adalah aplikasi chatting, seperti whatsapp, line, dan telegram. Kurang lebih $60.80 \%$ masyarakat menggunakan aplikasiaplikasi ini untuk menyebarluaskan hoax.

Kecenderungan ini sangat memprihatinkan, karena dua media tulisan ini pasti dimiliki oleh hampir semua orang, dari level pendidikan terendah (SD) sampai tinggi, apalagi kalau dilihat secara demografi survei Mastel memiliki karakteristik respon yang bervariasi, dan responden terbanyak, $46.50 \%$

Kementerian Koordinator Bidang Perekonomian, Kementerian Koordinator Bidang POLHUKAM. Adapun terkait kemitraan dengan legislatif, MASTEL secara aktif memberikan konsultasi kepada Komisi I DPR RI.

${ }^{20}$ Survei melibatkan 1.116 responden dan dirilis 7 Februari 2017, dimaksudkan untuk mendapatkan gambaran tentang persepsi masyarakat terhadap Hoax, penyebarannya, klasifikasi dan dampaknya kepada kehidupan berbangsa secara Nasional. berpendidikan S1 dan $14.70 \%$ S2, artinya responden survei ini kebanyakan kalangan terpelajar, karena itu masuk akal kalau $83.20 \%$ mereka menyingkapi berita hoax dengan cara re-check kebenarannya.

Di sinilah letak masalah. Realitas masyarakat yang heterogenistik sebagai pemberian sejarah dan paradoks dari sebuah kebebasan bermedia berwajah hoax harus segera diatasi oleh sebuah pendekatan baru, yaitu etika yang menjembatani kebebasan bermedia sebagai opsi hak untuk berkespresi dan fenomena hoax sebagai bawaan sebuah kebebasan tanpa batas. Terlepas dari berbagai motivasi yang menjadi latar belakang berkembangnya hoax di masyarakat, maka satu hal yang perlu dijaga adalah hoax tidak boleh dijadikan alat pemecah belah masyarakat yang memiliki struktur plural seperti Indonesia.

Penelitian ini berusaha mengkaji esensi kebebasan bermedia di Indonesia, yang tertuang dalam dokumen-dokumen kenegaraan, yaitu Undang-undang yang mengatur kehidupan media (pers) dari rejim orde baru sampai reformasi.

\section{METODE PENELITIAN}

Kajian ini menggunakan studi literatur, teristimewa analisis dokumen. Yang termasuk dalam analisis dokumen adalah analisis otobiografi, memoar, catatan harian, surat-surat pribadi, catatan pengadilan, berita koran, artikel majalah, brosur, buletin, dan foto-foto. ${ }^{21}$

Meskipun tidak secara langsung menyebut naskah undang-undang sebagai obyek analisis dokumentatif, namun kajiankajian subyektif layak menempatkan dokumen negara, seperti undang-undang sebagai obyek penelitian kualitatif untuk menempatkannya secara proporsional dalam konteks perkembangan sosial kemasyarakatan yang baru.

\footnotetext{
${ }^{21}$ Mulyana, Deddy. 2013. Metodologi Penelitian Kualitatif. Paradigma Baru Ilmu Komunikasi dan Ilmu Sosial lainnya. Bandung: Rosda Karya, hal. 195.
} 
Sejarah kebebasan media (pers) di Indonesia erat berhubungan dengan empat dokumentasi negara, sebagai berikut, yaitu: Undang-undang Ketentuan Pokok Pers No. 11 Tahun 1966; Perubahan Undang-undang Ketentuan Pokok Pers No. 21 Tahun 1982; Undang-undang No. 40 Tahun 1999, tentang Pers; dan Undang No. 11 Tahun 2008, tentang Informasi dan Transaksi Eletronik; dan atas perubahannya, yaitu Undang-undang No. 19 Tahun 2016.

Kelima dokumentasi ini dibaca secara kritis berdasarkan konteks yang baru saat ini, reformasi. Keseluruhan hasil kajian dihubungkan secara diametral dengan struktur masyarakat Indonesia yang begitu pluralisitk.

Lalu, dirancang sebuah jembatan pendamai yang menghubungkan idealisme media, yaitu kebebasan dengan fenomena surplus informasi berwajah hoax melalui pendekatan etika kewajiban media dalam masyarakat pluralistik, baik secara sosial dan keyakinan, maupun ideologi dan politik.

\section{HASIL DAN PEMBAHASAN}

\section{Hoax per Definisi}

Apa sih hoax itu sebenarnya? Dan, apa dampak darinya kalau tidak dikelola dengan bijaksana? The Contemporary English-Indonesian Dictionary ${ }^{22}$, mengartikan hoax sebagai senda gurau, olok-olok, bersendagurau, berolok-olok. The Oxford Thesaurus American Edition ${ }^{23}$, mengartikannya sebagai deception, fraud, swindle, trick, flam, or flim flam, imposture, cheat, humbug, mare's nest, slang con (game), gyp, scam, game, US snow job. Kamus Inggris-Indonesia: An EnglishIndonesian Dictionary, tulisan John Echols

\footnotetext{
${ }^{22}$ Salim, Peter. 1996. The Contemporary EnglishIndonesian Dictionary. Jakarta: Modern English Press., hal. 882.

${ }^{23}$ Urdang, Laurence. 1992. The Oxford Thesaurus American Edition. New York: Oxford University Press., hal., 211.
}

\& Hassan Shadily ${ }^{24}$, mengartikan hoax sebagai olok-olok, cerita bohong, dan memperdayakan. Kamus Besar Bahasa Indonesia ${ }^{25}$ tidak menggunakan kata hoax, tetapi dia menggunakan beberapa istilah yang dekat dengan pengertian hoax di atas yaitu: berita rekaan yang dibuat untuk tujuan tertentu; atau sensasi yang terlalu dibesarkan, untuk menarik perhatian masyarakat.

Gordon Stein dari Universitas California, berhasil menjelaskan bahwa hoax menyimpan banyak daya tarik tertentu bagi orang-orang. Pembuat hoax memanfaatkan orang-orang yang sukses membodohi orang lain, setidaknya beberapa orang untuk beberapa waktu, dan sadar atau tidak kita semua suka menipu orang lain. ${ }^{26}$

Dalam penjelasannya, Gordon Stein berusaha memisahkan hoax dari penipuan. ${ }^{27}$ Dia menegaskan penipuan selalu bermotif ekonomi, atau melibatkan uang, memiliki kualitas yang abadi. Atau, penipuan dilakukan secara eksklusif, terutama untuk menghasilkan uang. Hoax dan penipuan memang memiliki pemahaman yang saling tumpang tindih satu sama lain.

Dia juga menjelaskan tentang hubungan hoax, mitos dan legenda. Menurut Stein, bentuk penipuan yang bertahan lama, yang terus berlangsung tanpa diketahui dalam jangka waktu yang cukup lama, bisa saja dapat menjadi legenda atau mitos tertentu.

Berdasarkan informasi ensiklopedis dan pandangan yang ada maka hoax dapat disimpulkan ke dalam tiga pengertian berikut, yaitu: Pertama, hoax adalah berita bohong, artinya berita yang disampaikan tidak benar; tidak berdasarkan fakta dan kenyataan yang sebenarnya; berita tanpa data. Berdasarkan kesimpulan ini,

\footnotetext{
${ }^{24}$ Echols, John dan Hassan Shadily. 2000. Kamus Inggris-Indonesia, An English-Indonesian Dictionary. Jakarta: Gramedia, hal., 300.

${ }^{25}$ Departemen Pendidikan Nasional. 2008. Kamus Besar Bahasa Indonesia (Edisi ke-4). Jakarta: Gramedia, hal., 179.

${ }^{26}$ George, John. 1994. "Lies, Credulity, Ignorance, and More Lies", dalam Jurnal Council for Democratic $\&$ Secular Humanism Summer.

${ }^{27}$ Ibid.
} 
pertanyaan mengapa orang/kelompok orang gemar membuat berita tanpa data? Kita menemukan pengertian kedua, yaitu: hoax adalah berita yang sengaja dibuat untuk kepentingan tertentu, baik pada tataran kepentingan individu maupun kepentingan kelompok yang lebih besar. Kepentingankepentingan yang sangat kuat menggunakan hoax sebagai sarana memengaruhi adalah politik dan ideologi tertentu.

Mengapa untuk kepentingan politik dan ideologi orang/kelompok orang gemar menggunakan hoax? Kita menemukan pengertian ketiga, yaitu hoax adalah berita yang sengaja dibuat untuk memperdaya. Terminologi "memperdaya" dimaksudkan bahwa hoax sengaja mengeksploitasi persepsi khalayak untuk mempercayai sesuatu yang bersifat menipu, berbohong, sebagai sesuatu yang "seolah-olah" benar.

Kalau orang memercayai berita hoax maka hoax itu sendiri telah berhasil memperdaya khayalak, karena mereka terperangkap dalam pengertian yang salah atas sebuah fakta yang seharusnya benar.

\section{Idealisme Media: Membaca Regulasi}

Sejarah media suatu bangsa sangat ditentukan oleh bagaimana rejim sejarah menempatkan media untuk kekuasaan dan keberlangsungan kekuasaannya. Begitupun sejarah media di Indonesia. Orde Baru, melalui Undang-undang Ketentuan Pokok Pers, No. 11 Tahun $1966^{28}$ mendefinisikan media massa, atau menggunakan istilah pers sebagai lembaga kemasyarakatan alat revolusi yang mempunyai karya sebagai salah media komunikasi massa yang bersifat umum berupa penerbitan yang teratur waktu terbitnya, diperlengkapi atau tidak diperlengkapi dengan alat-alat miliki sendiri berupa percetakan, alat-alat foto, klise, mesin-mesin stensil atau alat-alat tehnik lainnya.

Tentang fungsi, kewajiban, dan hak pers Undang-undang ini mengatur, antara lain: Pers Nasional adalah alat revolusi dan merupakan mass-media yang bersifat aktif,

${ }^{28}$ Dokumentasi Undang-undang Ketentuan Pokok Pers No. 11 Tahun 1966. dinamis kreatif,edukatif, informatoris dan mempunyai fungsi kemasyarakatan pendorong dan pemupuk daya pikiran kritis dan progresip meliputi segala perwujudan kehidupan dan penghidupan masyarakat Indonesia.

Dalam Undang-undang ini ditegaskan bahwa pers Nasional memiliki kewajiban, antara lain: a). Mempertahankan, membela, mendukung, dan melaksanakan Pancasila dan UndangUndang Dasar 1945 secara murni dan konsekwen; b). Memperjuangkan pelaksanaan Amanat Penderitaan Rakyat, berlandaskan Demokrasi Pancasila; c). Memperjuangkan kebenaran dan keadilan atas dasar kebebasan pers; d). Membina persatuan dan kekuatan-kekuatan prograsif revolusioner dalam perjuangan menentang imperialisme, kolonialisme, neokolonialisme, feodalisme, liberalisme, komunisme, dan fasisme/diktatur; e). Menjadi penyalur pendapat umum yang konstruktif dan progresif revolusioner.

Menariknya, Undang-undang yang sama mengatur hak-hak media, seperti: hak kontrol, kritik dan koreksi yang bersifat korektif dan konstruktif; dan bahkan, kepada pers Nasional tidak dikenakan sensor dan pemberedelan; Kebebasan pers sesuai dengan hak azasi warga negara di jamin; Kebebasan pers ini didasarkan atas tanggung jawab nasional.

Dalam perjalanannya Undangundang ini pun dikoreksi lewat Undangundang perubahan, yaitu Undang-undang No. 21 tahun 1982..$^{29}$ Beberapa terminologi kemediamassan diganti dengan terminologi baru, sesuai kebutuhan rejim saat itu, seperti: terminologi alat revolusi diubah menjadi alat perjuangan Nasional; terminologi alat penggerak massa diubah menjadi alat penggerak pembangunan bangsa; Pengawal revolusi diubah menjadi pengawal ideologi Pancasila; Pers sosialis Pancasila diubah menjadi pers Pancasila; Tiga kerangka revolusi diubah menjadi

\footnotetext{
${ }^{29}$ Dokumentasi Undang-undang Ketentuan Pokok
} Pers No. 21 Tahun 1982. 
tujuan Nasional; Progresif diubah menjadi konstruktif-progresif; Kontra revolusi diubah menjadi menentang Pancasila; dan, Berkhianat terhadap revolusi diubah menjadi berkhianat terhadap perjuangan Nasional.

Kita juga tahu bahwa dari perkembangan sejarahnya, masa emas kebebasan bermedia di Indonesia justru dialami rejim bernama reformasi. Nada dasar pembentuk keterbukaan informasi dalam rejim reformasi ini adalah demokratisasi. Rakyat diberi ruang untuk merasa memiliki hak memanfaatkan berbagai alat reformasi dalam rerangka menyuarakan, tidak saja keinginannya, tetapi juga berbagai kepentingannya untuk negara dan masyarakat. Regulasi media pun ikut dirubah senapas dengan ide dasar reformasi politik, sosial, dan ideologi.

Atas dasar argumentasi dan penjelasan demokratisasi itulah maka rejim reformasi menelorkan sebuah Undangundang Pers yang baru, yaitu: Undangundang No. 40 Tahun $1999^{30}$, tentang Pers.

Undang-undang ini memuat ketentuan umum sebagai berikut: Pers adalah lembaga sosial dan wahana komunikasi massa yang melaksanakan kegiatan jurnalistik meliputi mencari, memperoleh, memiliki, menyimpan, mengolah, dan menyampaikan informasi baik dalam bentuk tulisan, suara, gambar, suara dan gambar, serta data dan grafik maupun dalam bentuk lainnya dengan menggunakan media cetak, media elektronik, dan segala jenis saluran yang tersedia.

Mengenai asas, fungsi, hak, kewajiban, dan peranan pers Undangundang ini menegaskan antara lain: Kemerdekaan pers adalah salah satu wujud kedaulatan rakyat yang berasaskan prinsipprinsip demokrasi, keadilan, dan supremasi hukum; Pers nasional mempunyai fungsi sebagai media informasi, pendidikan, hiburan,dan kontrol sosial.

\footnotetext{
${ }^{30}$ Dokumentasi Undang-undang Pers No. 40 Tahun 1999.
}

Kemerdekaan pers dijamin sebagai hak asasi warga negara; Terhadap pers nasional tidak dikenakan penyensoran, pembredelan atau pelarangan penyiaran; Untuk menjamin kemerdekaan pers, pers nasional mempunyai hak mencari, memperoleh, dan menyebarluaskan gagasan dan informasi.

Dalam mempertanggungjawabkan pemberitaan di depan hukum, wartawan mempunyai Hak Tolak; Pers nasional berkewajiban memberitakan peristiwa dan opini dengan menghormati norma-norma agama dan rasa kesusilaan masyarakat serta asas praduga tak bersalah; Pers wajib melayani hak jawab; Pers wajib melayani hak tolak.

Peranan pers menurut Undangundang ini antara lain: Memenuhi hak masyarakat untuk mengetahui; menegakkan nilai-nilai dasar demokrasi, mendorong terwujudnya supremasi hukum, dan hak asasi manusia, serta menghormati kebhinekaan; Mengembangkan pendapat umum berdasarkan informasi yang tepat, akurat dan benar; Melakukan pengawasan, kritik, koreksi, dan saran terhadap hal-hal yang berkaitan dengan kepentingan umum; memperjuangkan keadilan dan kebenaran.

Bagi penulis, regulasi yang dihasilkan lewat Undang-undang maupun perubahan atas Undang-undang itu adalah kondisi ideal cita-cita bermedia dalam negara. Terlepas dari apapun praktik media dan bagaimana rejim memandang dan memanfaatkan media, kebebasan berekspresi sebenarnya telah diakomodasikan oleh Undang-undang yang ada, artinya dari sisi regulasi ketatanegaraan keberlangsungan media di Indonesia dijamin dan sudah diatur secara konstitusional.

\section{Media Sosial sebagai Media Massa?}

Namun, perkembangan media yang tidak diduga oleh ketiga Undang-undang di atas pertumbuhan media sosial baru. Tidak ada satupun, pasal dalam Undang-undang di atas menyentuh, atau menyinggung eksistensi media sosial. 
Meskipun, belum ada kesepakatan memasukan media sosial sebagai bagian dari media massa, pengaruh dan sepak terjang media sosial dewasa begitu sulit dikendalikan, bahkan dipercayai pengaruhnya melampaui kepercayaan kepada media-media massa mainstream.

Fenomena ini kiranya mendorong negara menempatkan kasus media sosial sebagai kasus luar biasa. Pengaturannya tidak begitu saja disamakan dengan mengatur media-media massa mainstream. Negara mengatur pergerakan media sosial dalam Undang-undang khusus, yang kita kenal dengan Undang-undang No. 11 Tahun 2008, tentang Informasi dan Transaksi Elektronik. ${ }^{31}$

Secara garis besar Undang-undang ini mengatur dua hal penting, yaitu: Pertama, mengatur informasi elektronik; dan yang kedua, mengatur transaksi elekronik. Undang-undang ini mendefinisikan informasi elektronik sebagai satu atau sekumpulan data elektronik, termasuk tetapi tidak terbatas pada tulisan, suara, gambar, peta, rancangan, foto, electronic datainterchange $(E D I)$, surat elektronik (electronic mail), telegram, teleks, telecopy atau sejenisnya, huruf, tanda, angka, kode Akses, simbol, atau perforasi yang telah diolah yang memiliki arti atau dapat dipahami oleh orang yang mampu memahaminya.

Sedangkan transaksi elektronik didefinisikan sebagai perbuatan hukum yang dilakukan dengan menggunakan komputer, jaringan komputer, dan/atau media elektronik lainnya. Teknologi informasi adalah suatu teknik untuk mengumpulkan, menyiapkan, menyimpan, memproses, mengumumkan, menganalisis, dan/atau menyebarkan informasi.

Pertanyaannya, apa hubungan antara Undang-undang ini dengan media sosial? Kenyataannya, dia tidak mengatur media sosial. Kita tahu bahwa pola distribusi informasi melalui media sosial

\footnotetext{
${ }^{31}$ Dokumentasi Undang-undang tentang Informasi dan Transaksi Elektronik No. 11 Tahun 2008.
}

pasti selalu berbasis teknologi informasi, maka atas dasar itu pula maka pelanggaran atas distribusi informasi elektronik pun harus dijelaskan dalam konteks informasi berbasis teknologi tersebut.

Sekurang-kurangnya terdapat tiga pasal khusus yang dipakai untuk menjerat secara hukum para pemakai media sosial bermasalah, yaitu: (1) pasal 27: Setiap orang dengan sengaja dan tanpa hak mendistribusikan dan/atau mentransmisikan dan/atau membuat dapat diaksesnya informasi elektronik dan/atau dokumen elektronik yang memiliki muatan yang melanggar kesusilaan; Setiap orang dengan sengaja dan tanpa hak mendistribusikan dan/atau mentransmisikan dan/atau membuat dapat diaksesnya informasi elektronik dan/atau dokumen elektronik yang memiliki muatan perjudian; Setiap orang dengan sengaja dan tanpa hak mendistribusikan dan/atau mentransmisikan dan/atau membuat dapat diaksesnya informasi elektronik dan/atau dokumen elektronik yang memiliki muatan penghinaan dan/atau pencemaran nama baik; Setiap orang dengan sengaja dan tanpa hak mendistribusikan dan/atau mentransmisikan dan/atau membuat dapat diaksesnya informasi elektronik dan/atau dokumen elektronik yang memiliki muatan pemerasan dan/atau pengancaman.

Kata kunci yang harus dihindari pemakai media sosial sehubungan dengan pasal ini, antara lain mendistribukan segala hal bermuatan (1) kesusilaan, (2) perjudian, (3) penghinaan dan pencemaran nama baik, (4) pemerasan dan pengancaman.

Pasal 28: Setiap orang dengan sengaja dan tanpa hak menyebarkan berita bohong dan menyesatkan yang mengakibatkan kerugian konsumen dalam transaksi elektronik; dan, Setiap orang dengan sengaja dan tanpa hak menyebarkan informasi yang ditujukan untuk menimbulkan rasa kebencian atau permusuhan individu dan/atau kelompok masyarakat tertentu berdasarkan atas suku, agama, ras, dan antargolongan (SARA).

Kata kunci yang menjadi pegangan pemakai media sosial antara lain: (1) 
Menyebarkan berita bohong dan menyesatkan; dan (2) Menyebarkan informasi yang menimbulkan kebencian dan permusuhan berdasarkan kategori suku, agama, ras, dan antargolongan (SARA).

Pasal 29: Setiap orang dengan sengaja dan tanpa hak mengirimkan informasi elektronik dan/atau dokumen elektronik yang berisi ancaman kekerasan atau menakut-nakuti yang ditujukan secara pribadi.

Kata kunci yang harus dihindari adalah mengirimkan informasi elektronik berisi ancaman, atau menebarkan rasa takut yang diarahkan kepada orang pribadi.

Meskipun telah dilakukan revisi dengan Undang-undang perubahan No. 19 Tahun 2016, namun pasal-pasal informasi elektronik dan transaksi elektronik yang menyasar pada media sosial (pasal 27, 28, 29) tidak mengalami perubahan, artinya sampai pada tahapan revisi pasal-pasal ini tetap sama seperti yang tertulis pada Undang-undang No. 11 Tahun 2008.

Pertanyaan lainnya adalah bagaimana kita memosisikan media sosial dalam keseluruhan konteks media massa? Kalau kita merujuk pada definisi media massa sebagaimana digambarkan Denis McQuail $^{32}$, sebagai model komunikasi yang berlangsung dalam skala yang besar dan dilengkapi dengan media baru, terutama internet dan teknologi seluler, dengan kapasitas transmisi teks dan gambar secara instan dan cepat, maka tidak ada alasan bagi kita untuk tidak menempatkan media sosial sebagai media massa.

Atau, definisi media massa yang dikemukakan oleh Roger D. Wimmer dan Joseph R. Dominick ${ }^{33}$, bahwa media massa selalu mengacu pada segala bentuk komunikasi yang secara simultan menjangkau banyak orang, termasuk di dalamnya pemanfaatan media yang tidak

\footnotetext{
${ }^{32}$ Watson, James dan Anne Hill. 2012. Dictionary of Media Studies (8th Edition). New York: Bloomsbury Puslishing, hal., hal 165.

${ }^{33}$ Wimmer, Roger D. Dan Joseph R. Dominick. 2011. Mass Media Research, An Introduction (Ninth Edition). Boston: Wardsworth Cengage Learning, hal., 2.
}

terbatas, seperti: radio, televisi, surat kabar, majalah, papan iklan, film, rekaman, buku, dan juga internet.

Kita dapat menyiimpulkan bahwa media sosial dapat dikategorikan sebagai media massa berdasarkan tiga pertimbangan berikut, antara lain: Pertama, dari sisi pengaruh, dia memengaruhi hampir seluruh aspek kehidupan masyarakat; Kedua, dari sisi jangkauan. Media sosial menjangkau banyak orang hampir semua lapisan masyarakat; Ketiga, dari sisi media yang dipakai. Media sosial menggunakan berbagai fitur media baru, seperti internet dengan proses transmisi yang cepat; Keempat, semua yang terlibat dalam media sosial, baik dalam peran sebagai komunikator maupun komunikan, berinteraksi secara simultan (interaktif) dalam ruang dan waktu yang bersamaan.

\section{Apa yang terjadi?: Catatan Kritis Media Orde Baru}

Di atas sudah dijelaskan bahwa semua regulasi perundang-undangan yang diciptakan negara, baik di rejim orde baru maupun di orde reformasi selalu menempatkan media dan peranannya dalam kondisi ideal. Namun, apa yang terjadi dalam kenyataannya? Berikut catatan (kritis) yang bisa diberikan terhadap idealisme media yang digambarkan dalam beberapa Undang-undang yang diciptakan negara: Terhadap kebijakan media orde baru (Undang-undang Ketentuan Pokok Pers No. 11 Tahun 1966 dan Undangundang Ketentuan Pokok Pers No. 21 Tahun 1982), sekurang-kurangnya terdapat empat kritik fundamental, yang disebut sebagai contraditio in terminis, yaitu: Pertama, pengaturan dalam Undangundang, terutama pasal 4, "terhadap pers Nasional tidak dikenakan sensor dan pembreidelan",34, secara mengejutkan kontradiktif dalam kenyataannya.

Di masa pemberlakuan kedua Undang-undang ini sejarah mencatat,

\footnotetext{
${ }^{34}$ Dokumentasi Undang-undang Ketentuan Pokok Pers No. 11 Tahun 1966\&Dokumentasi Undangundang Ketentuan Pokok Pers No. 21 Tahun 1982.
} 
terjadinya tumpang tindih peraturan dan praktik peraturan yang membelenggu kebebasan media, antara lain: Permenpen Nomor 2 Tahun 1969 tentang KetentuanKetentuan Pokok Wartawan; Surat Keputusan (SK) Menpen Nomor 214 Tentang Prosedur dan Persyaratan untuk Mendapatkan SIUPP; SK Menpen Nomor 47 Tahun 1975 tentang Pengukuhan PWI dan Serikat Pekerja Surat Kabar Sebagai Satu-Satunya Organisasi Wartawan dan Organisasi Penerbit Pers Indonesia; dan Peraturan Menteri Penerangan Nomor 1 tahun 1984 tentang Ketentuan-Ketentuan Surat Izin Usaha Penerbitan Pers (SIUPP). Dampaknya, sejarah kelam kebebasan media versi regulasi Negara dan praktik rejim yang diktatur otoritarian membreidel dengan sengaja tiga media kritis, yaitu: Majalah Tempo, Majalah Editor, dan Tabloit Detik, tanggal 21 Juni 1994. Peristiwa ini oleh banyak pengamat media dianggap sebagai "paling dramatis" 35 dalam rejim Soeharto terhadap kebebasan media, lewat tangan besi Menteri Penerangan, Harmoko.

Kedua, berdasarkan kritik pertama, kebebasan media di periode sejarah ini dapat disebut sebagai kebebasan semu, artinya seolah-olah bebas, tetapi sesungguhnya tidak bebas. Tampaknya negara memberi ruang kebebasan media, lewat regulasi Undang-undang tetapi sesungguhnya, dalam kenyataannya media tidak pernah mengalami kebebasan tersebut.

Ketiga, terminologi hak kontrol, kritik dan koreksi yang bersifat konstrukstif, dalam pasal 3, bersifat mengelabui, dan bahkan menjebak media, artinya media diberi ruang mengontrol, mengoreksi, dan melakukan kritik, namun kenyataannya penggunaan ketiga hak ini dapat saja dianggap sebagai tindakan subversif, melawan kebijakan pemerintah yang sah. Tiga media yang disebutkan di

\footnotetext{
${ }^{35}$ William, Louise and Roland Rich (ed.). 2013. Losing Control: Freedom of the Press in Asia. Canberra: Australian National University Press, hal. 82.
}

atas menjadi contoh tindakan menjebak dan mengelabui tersebut.

Keempat, penekanan pasal 5 ayat 1 , bahwa kebebasan pers sesuai dengan hak asasi manusia warga negara, juga kontradiksi dalam kenyataannya. Bahwa negara seharusnya dianggap melakukan pelanggaran terhadap hak asasi manusia ketika melakukan penyensoran dan pembreidelan terhadap media.

Kalau asumsi hak kontrol, kritik, dan koreksi-kontruktif dipakai sebagai dasar, maka pembereidelan Majalah Tempo, Majalah Editor, dan Tabloit Detik dianggap sebagai tindakan pemerintah yang benar karena ketiga media ini tidak mampu mengemban ketiga hak yang dirumuskan negara.

Atas dasar itulah, dapat dimengerti, mengapa negara merasa tidak melakukan pelanggaran atas hak asasi apa pun dalam pembreidelan tersebut. Pertanyaannya, apakah tidak ada pelanggaran atas sebuah regulasi yang jelas-jelas diudang-undangkan? Contradictio in Terminis!

\section{Media Reformasi}

Bagaimana nasib media dalam regulasi rejim reformasi? Perkembangan media di era reformasi justru menarik, tidak saja karena kebebasan benar-benar dinikmati, tetapi lebih itu, ada pengaruh di balik kebebasan tersebut adalah suatu keadaan seperti tanpa kontrol. ${ }^{36}$

Seperti digambarkan sebelumnya bahwa pengaturan media dalam orde reformasi tertuang melalui Undang-undang No. 40 Tahun 1999, tentang Pers. Undangundang ini sebenarnya sangat komprehensif karena mampu menjawabi kebutuhan baru reformasi.

Sama idealnya dengan Undangundang media orde baru, Undang-undang ini justru berbeda pada tingkat pelaksanaan. Media orde baru secara ideologis bebas, namun terkekang dalam pelaksaannya; Hal

\footnotetext{
${ }^{36}$ Opcit. William, Louise and Roland Rich (ed.). 2013. Losing Control: Freedom of the Press in Asia. Canberra: Australian National University Press.
} 
yang sama terjadi pada media reformasi, secara ideologis bebas, namun pada pelaksanaannya nampak "losing control"37

Meskipun lima pasal yang mengatur asas, fungsi, hak, kewajiban, dan peranan media, nampak sudah mengakomodasikan cita-cita media reformasi dalam nada dasar kebebasan demokratis, namun perlu pula secara kritis diwaspadai tiga persoalan mendasar sebagai contradictio in terminis, berikut, yaitu: Pertama, media sebagai lembaga ekonomi bisa ditafsir sebagai ruang bagi perusahaan media untuk membangun kapitalisme media. Kapitalisme media bisa saja mengaburkan idealime media sebagai sarana informasi dan pendidikan, lalu lebih mengutamakan, atau menggeser peran dominan sebagai sarana hiburan saja. Kenyataan ini saja sulit dikontrol negara. ${ }^{38}$

$$
\text { Kedua, terminologi "tidak }
$$

dikenakan penyensoran, pembredelan, atau pelarangan penyiaran" dan "pers nasional mempunyai hak untuk mencari, memperoleh, dan menyebarluaskan gagasan dan informasi" ${ }^{39}$ bisa saja kontradiksi kalau media menggunakan kebebasan (tidak ada sensor) sebagai alat untuk memperkuat hak menyebarkan informasi saja tanpa kewajiban apapun.

Kalau itu terjadi maka kebebasan media menjadi bertentangan dengan prinsip keadilan. Kita tahu bahwa prinsip keadilan selalu menuntut agar hak warga negara memperoleh informasi dipenuhi media sebagai kewajiban dengan memberi informasi yang mendidik dan mencerahkan warga negara.

Ketiga, terminologi "menghormati norma-norma agama dan rasa kesusilaan masyarakat" di pasal 5 dan "menghormati kebhinekaan" di pasal 6 poin $\mathrm{b}$, sudah cukup bagi Negara untuk mengakomodasikan kebutuhan warga mendapatkan informasi media yang sehat dan bertanggung jawab, namun apa yang terjadi, di masa pemberlakukan regulasi ini

\footnotetext{
${ }^{37}$ Ibid.

${ }^{38}$ Pasal 3, Undang-undang Pers No. 40 Tahun 1999.

${ }^{39}$ Pasal 4, Undang-undang Pers No. 40 Tahun 1999.
}

masyarakat disuguhkan berbagai informasi yang tidak sehat: pornografi, kekerasan, konten pemberitaan media sosial bermuatan SARA, dan hoax, berita bohong, serta menyesatkan sepertinya mendominasi pengetahuan masyarakat ketimbang media sebagai sarana informasi sehat dan mendidik.

Kenyataan ini terbaca jelas dalam Laporan Tahunan Kementerian Komunikasi dan Informatika tahun $2017^{40}$, yang dirilis bulan Juli 2018, bahwa dari 60.135 aduan situs negatif, 19.778 diantaranya kasus pornografi; 16.742 kasus SARA; 7.795 kasus fitnah; 7.246 kasus perjudian; 2.950 kasus penipuan; 1.691 konten yang meresahkan; 1.586 kasus terorisme dan radikalisme; 739 kasus pelanggaran HAKI; 150 kasus kekerasan terhadap anak, 142 kasus keamanan internet; dan banyak kasus lainnya.

Beruntung bahwa Kementerian Komunikasi dan Informatika berhasil memblokir lebih banyak dari aduan-aduan masyarakat ini. Tercatat berhasil diblokir 776.882 situs-situs pornografi; situs SARA diblokir sebanyak 183; situs-situs penipuan berhasil diblokir sebanyak 2.808; situs narkoba diblokir sebanyak 89; situs perjudian sebanyak 7.443 ; situs radikalisme diblokir sebanyak 202; situs kekerasan terhadap anak sebanyak 150 situs; dan HKI sebanyak 361 situs. $^{41}$

Barangkali ini kelemahan mendasar dari Undang-undang No. 40 Tahun 1999, bahwa media sosial tidak dianggap sebagai pers, padahal dampaknya luar biasa masifnya dibandingkan media-media mainstream. Siapa saja bisa menjadi wartawan tanpa kontrol apapun dari Negara. Inilah yang dimanfaatkan media sosial, Undang-undang No. 40 Tahun 1999, tampak hanya mengatur konten-konten pemberitaan media-media mainstream.

\footnotetext{
${ }^{40}$ Laporan Tahunan Kementerian Komunikasi dan Informatika Tahun 2017, Juli 2018, hal. 26. ${ }^{41}$ Ibid.
} 


\section{Informasi \& Transaksi Elektronik: Hakim Media Sosial}

Kelahiran Undang-undang No. 11 Tahun 2008, tentang Informasi dan Transaksi Elektronik, dapat dilihat sebagai momentum pengaturan media sosial setara dengan media-media mainstream. Kenyataannya kebebasan tanpa batas media, tidak terjadi pada media mainstream, melainkan pada media-media sosial. Maka, pengaturan atasnya harus dilihat sebagai suatu kewajiban konstitusional Negara atas hak warga untuk mendapatkan informasi yang mendidik.

Meskipun Undang-undang ini mengatur informasi elektronik dan transaksi elekronik, tulisan ini hanya berkepentingan membahas informasi elektronik saja karena berkaitan dengan segala bentuk berita, informasi, dan pengetahuan masyarakat yang diperoleh dengan memanfaatkan berbagai mekanisme elektronik sebagai media pengetahuannya.

Kita tahu bahwa Undang-undang ini mendefinisikan informasi elektronik sebagai satu atau sekumpulan data elektronik, termasuk tetapi tidak terbatas pada tulisan, suara, gambar, peta, rancangan, foto, electronic data interchange (EDI), surat elektronik (electronic mail), telegram, teleks, telecopy atau sejenisnya, huruf, tanda, angka, kode Akses, simbol, atau perforasi yang telah diolah yang memiliki arti atau dapat dipahami oleh orang yang mampu memahaminya.

Merujuk pada definisi ini maka, kurang lebih terdapat tiga pasal penting yang harus dijadikan pegangan para pengguna media sosial, yaitu: Pasal 27, Pasal 28, dan pasal 29. Mengulang kutipan sebelumnya bahwa pasal 27 berbunyi sebagai berikut: Setiap orang dengan sengaja dan tanpa hak mendistribusikan dan/atau mentransmisikan dan/atau membuat dapat diaksesnya informasi elektronik dan/atau dokumen elektronik yang memiliki muatan yang melanggar kesusilaan; Setiap orang dengan sengaja dan tanpa hak mendistribusikan dan/atau mentransmisikan dan/atau membuat dapat diaksesnya informasi elektronik dan/atau dokumen elektronik yang memiliki muatan perjudian; Setiap orang dengan sengaja dan tanpa hak mendistribusikan dan/atau mentransmisikan dan/atau membuat dapat diaksesnya informasi elektronik dan/atau dokumen elektronik yang memiliki muatan penghinaan dan/atau pencemaran nama baik; Setiap orang dengan sengaja dan tanpa hak mendistribusikan dan/atau mentransmisikan dan/atau membuat dapat diaksesnya informasi elektronik dan/atau dokumen elektronik yang memiliki muatan pemerasan dan/atau pengancaman.

Sementara pasal 28, bunyi antara lain: Setiap orang dengan sengaja dan tanpa hak menyebarkan berita bohong dan menyesatkan yang mengakibatkan kerugian konsumen dalam transaksi elektronik; dan, Setiap orang dengan sengaja dan tanpa hak menyebarkan informasi yang ditujukan untuk menimbulkan rasa kebencian atau permusuhan individu dan/atau kelompok masyarakat tertentu berdasarkan atas suku, agama, ras, dan antargolongan (SARA).

Dan, pasal 29: Setiap orang dengan sengaja dan tanpa hak mengirimkan informasi elektronik dan/atau dokumen elektronik yang berisi ancaman kekerasan atau menakut-nakuti yang ditujukan secara pribadi.

Kalau mau diringkas ketiga pasal ini mengatur siapa saja yang memanfaatkan media sosial sebagai alat mengumpulkan, mengelola, dan menyebarluaskan informasi untuk menghindari sejauh mungkin hal-hal sensitif sebagai berikut: Kesusilaan; Perjudian; Penghinaan dan pencemaran nama baik; Pemerasan dan pengancaman; Menyebarkan berita bohong dan menyesatkan; Menyebarkan informasi yang menimbulkan kebencian dan permusuhan berdasarkan kategori suku, agama, ras, dan antargolongan (SARA); dan Mengirimkan informasi elektronik berisi ancaman, atau menebarkan rasa takut yang diarahkan kepada orang pribadi.

Disadari, atau tidak disadari sumber kekacauan sosial akibat pemakaian media sosial dengan muda ditemukan. Siklus penyampaian kebencian, kebohongan, hoax, 
kekerasan, dan penipuan dengan muda dilakukan karena diinstrumentalisasi oleh seperangkat gawai mungil di tangan melalui facebook, twitter, Instagram, Path.

$$
\text { Hasil Survei Masyarakat }
$$

Telematika Indonesia (MASTEL) 7 Februari 2017, membenarkan itu, bahwa $62.10 \%$ tulisan hoax berasal dari facebook, twitter, Instagram, dan Path. ${ }^{42}$

Kebijakan pemerintah meregistrasi kartu prabayar dari nomor handphone barangkali bisa dilihat dari kaca mata positif agar pengguna media sosial pemakai kartu prabayar bertanggung atas apapun yang berhubungan dengan gawainya.

Masalah keamanan warga adalah tanggung jawab Negara. Makanya, kebijakan registrasi kartu prabayar harus dimengerti dari sisi manfaat ini: (1) Menertibkan data pelanggan seluler agar sesuai dengan data kependudukan; (2) Mencegah kejahatan, seperti penipuan dan pesan-pesan sampah (spam); (3) Mencegah tindak terorisme: (4) dan, Mengatasi hoax. ${ }^{43}$

\section{Etika Komunikasi Digital: Mempertimbangkan Pluralitas Sosial sebagai Keharusan}

Kehadiran media sosial yang sulit dikendalikan mau tidak mau harus diperhadapkan dengan seluruh konteks sosial masyarakat kita. Kenyataan sosial sebagai konteks masyarakat kita tidak lain adalah pluralitas (suku, agama, ras, dan antargolongan/SARA).

F. Budi Hardiman mensinyalir bahwa masyarakat informasi saat ini sedang menghadapi dua ekstrem sekaligus, ekstrem yang satu disebut sebagai radikalisme/fundamentalisme agama dengan munculnya kekuatan-kekuatan kontrasivilisasi dan ekstrem yang satu lagi adalah relativisme nilai dalam wujud post-

\footnotetext{
${ }^{42}$ Opcit., Survei Masyarakat Telematika Indonesia. 2017.

${ }^{43}$ Opcit. Laporan Tahuan Kementerian Komunikasi \& Informatika tahun 2017, hal. 21.
}

truth politics, narkoba, korupsi, dan human trafficking. ${ }^{44}$

Menghadapi sinyalemen ini dibutuhkan sebuah proses resivilisasi (pemberadaban kembali), yaitu proses moralisasi dan juridifikasi dunia digital dan penguatan ruang publik politis, yaitu media. Resivilisasi harus pula menyangkut penataan komunikasi digital untuk mencegah pemakaian kekerasan verbal dan intimidasi kekerasan dalam demokrasi, seperti: adanya ujaran kebencian, sentimentalisasi agama, dan disinformasi. ${ }^{45}$

Sederhananya, bahwa situasi masyarakat dengan kompleksitas keragaman, seperti Indonesia, pola pemberitaan media, apapun, entah itu media mainstream atau media sosial, harus selalu berpegang pada prinsip etis ketika mengumpulkan, menentukan sumber berita, sampai kepada menyiarkan berita tersebut kepada masyarakat.

Kita tahu bahwa perilaku komunikasi masyarakat maya sekarang ini menjadi model perilaku korporeal, Perilaku korporeal adalah perilaku dimana garis batas antara yang publik dan privat menjadi kabur, maka publik yang seharusnya rasional menjadi lebih sentimental. Publik menjadi begitu rentan terhadap kecemasan lingkungannya dan terus menerus mengalami information anxiety. ${ }^{46}$

Atau, menggunakan terminologi lain bahwa media sosial cenderung merubah identitas seseorang. Ketika seseorang terlibat dalam hubungan di media sosial seseorang bisa saja memilih dan benar-benar menciptakan identitas baru, dari penggunaan nama samaran sampai kepada penemuan seluruh karakter diri dalam komunitas online. Identitas offline dan online dapat bervariasi secara radikal,

\footnotetext{
${ }^{44}$ Hardiman, F. Budi. 2017. "Keadilan dan Keadaban dalam Perspektif Filsafat dan Ajaran Sosial Gereja". Materi Seminar. Jakarta

${ }^{45}$ Ibid.

${ }^{46}$ Ibid.
} 
meskipun kedua aspek tersebut terintegrasi dalam satu konsep diri. ${ }^{47}$

Kalau kita sepakat dengan prinsip norma moral dipakai sebagai pegangan hidup atau sebagai standar penilaian atas suatu tindakan disebut sebagai baik-buruk, benar-salah ${ }^{48}$, atau etika dimengerti sebagai sarana orientasi bagi manusia untuk menjawab pertanyaan bagaimana seharusnya hidup dan bertindak ${ }^{49}$, maka media, yang dikendalikan sepenuhnya sebagai tindakan manusiawi ${ }^{50}$, mau tidak mau harus menempatkan dirinya dalam prinsip etika sebagai keharusan moral.

Bertolak dari hasil survei yang dilakukan Masyarakat Telekomunikasi Indonesia, kita tahu bahwa media sosial, seperti: facebook, twitter, instagram, dan path adalah media terbanyak menyebarkan berita hoax. Sebanyak $92.40 \%^{51}$ hoax di Indonesia disebarkan melalui media sosialmedia sosial ini.

Upaya Masyarakat Anti Fitnah Indonesia (Mafindo) perlu diapresiasi karena berusaha mengembalikan jati diri bangsa dengan gerakan anti hoax. Gerakan masyarakat ini mengkuatirkan dampak serius hoax bagi masyarakat. Fenomena hoax yang masif bisa merusak pertemanan antar sahabat, keluarga menjadi tidak harmonis, dan yang paling ditakutkan adalah menyebarnya konflik horizontal dalam masyarakat, seperti pernah terjadi di Pilkada DKI. ${ }^{52}$

\footnotetext{
${ }^{47}$ Salvi, Maurizio. 2012. Ethics of Information and Communication Technologies. Luxemberg: European Commission., hal. 39.

${ }^{48}$ Sudarminta, J. 2013. Etika Umum. Kajian tentang Beberapa Masalah Pokok dan Teori Etika Normatif. Yogyakarta: Kanisius, hal. 3.

${ }^{49}$ Suseno, Franz Magnis. 1987 (cetakan 15, 2017). Etika Dasar. Masalah-Masalah Pokok Filsafat Moral. Yogyakarta: Kanisius, hal., 13.

${ }^{50}$ Tindakan manusiawi dipakai K. Bertens untuk mengungkapkan bahwa etika dipakai sebagai konsep moralitas, dan moralitas itu yang mencirikan manusia, dalam Etika (Revisi). 2013. Yogyakarta: Kanisius, hal., 10.

${ }^{51}$ Opcit., Survei Masyarakat Telematika Indonesia. 2017.

${ }^{52}$ Nugroho, Septiaji Eko. 2017. "Upaya Masyarakat Anti Fitnah Indonesia Mengembalikan Jatidiri Bangsa dengan Gerakan Anti Hoax", Prosiding pada
}

Karena itu kita membutuhkan sebuah standar etika komunikasi digital sebagai keharusan moral bagi pengguna media sosial sehingga dampak dari pemakaiannya tidak merusak tatanan sosial masyarakat kita yang beragam dan kompleks.

Komunikasi internet bukanlah lingkungan etis yang netral, dia adalah ruang interaksi sosial yang perlu menciptakan nilai-nilai dan normanormanya sendiri. Komunikasi internet tetap harus diletakan dalam kerangka jaringan nilai dan prinsip tindakan normatif, yaitu: penghargaan terhadap martabat, hak asasi manusia,dan berbagai tindakan non diskriminasi serta perlindungan kelompokkelompok rentan (minoritas). ${ }^{53}$

Karena, bagaimana pun juga berbicara tentang identitas moral, melibatkan lebih dari sekadar melindungi hak-hak seseorang terhadap orang lain atau bahkan negara. Identitas moral selalu menyangkut tanggung jawab tertentu, baik pada tingkat sosial (hukum) maupun pada level individu.

Kita tahu bahwa penindasan individu dalam jejaring sosial tidak akan hilang hanya karena penegakan peraturan dan hukum, tetapi perlu pula kesadaran hakiki bahwa individu memiliki kewajiban untuk melindungi orang lain dari kekerasan media sosial dan internet (cyber crime).

Karena itu ketika seseorang memutuskan untuk bebas berbagi data yang menyangkut ruang lingkup privasinya di media sosial, harus disadari pula bahwa keputusan tersebut tidak hanya mempengaruhi kebebasan dirinya sebagai individu tetapi dia memiliki implikasi luas bagi semua pengguna lainnya. ${ }^{54}$

Secara umum kita bisa menempatkan beberapa standar etis untuk menghindari hoax ketika memanfaatkan media sosial sebagai sarana membangun relasi dengan orang lain. Isu-isu terpenting

Konferensi Nasional Peneliti Muda Psikologi Indonesia, Vol. 2, No. 1, hal 1-4.

${ }^{53}$ Op.cit. Salvi, Maurizio. 2012, hal. 43.

${ }^{54}$ Ibid., hal. 45. 
etika bermedia ${ }^{55}$ dalam masyarakat plural perlu menjadi patokan utama dalam memanfaatkan media sosial.

Kita bisa menyebut beberapa standar etis konstitusional tersebut, antara lain: Pertama, kepatuhan kepada hukum media (sosial) untuk menghindari perilaku fitnah. Kita tahu bahwa fitnah adalah bagian dari kritik, tetapi kritik dengan cara fitnah selalu berorientasi pada penyerangan terhadap reputasi dan karakter seseorang. Penegakan hukum media (sosial) yang tertuang dalam Undang-undang Informasi \& dan Transaksi Elektronik perlu mendapat perhatian serius warga negara pemakai media sosial.

Kedua, menjunjung tinggi akurasi dalam penyampaian pesan. Akurasi pesan dapat dilakukan dengan beberapa cara, misalnya penentuan sumber pesan/berita/informasi yang dapat dipercaya. Hoax selau dipastikan berasal dari sumber yang tidak jelas. Media massa selalu berpegang pada prinsip check and recheck untuk menguji akurasi, sayang media sosial tidak selalu, bahkan tidak pernah mematuhi prinsip etis ini.

Ketiga, memperhitungkan hak istimewa (privilege) yang melekat pada seseorang. Ada absolute privilege, qualified privilege, dan person of interest. ${ }^{56}$ Etika kritik dalam tiga hak ini harus bersifat adil, dalam pengertian kritik yang tidak diarahkan untuk menyerang unsur-unsur pribadi pada mereka yang memiliki ketiga hak istimewa ini.

Keempat, menghindari pengungkapan secara publik urusan privat orang lain. Ruang privat seharusnya menjadi ruang di mana seseorang menjadi dirinya sendiri. Media sosial dengan mudah mengubah ruang pribadi (private sphere) menjadi ruang komunal (public sphere) dimana apa yang menjadi wilayah urusan pribadi dengan mudah diakses untuk menjadi ruang bersama dengan segala kepentingan di baliknya.

${ }^{55}$ Rich, Carole. 2010. Writing and Reporting News. A. Coaching Method. Boston: Wadsworth USA., hal. 289-295.

${ }^{56}$ Ibid., hal., 297.
Kelima, menghindari penyampaian pesan yang bersifat membohongi, atau menipu khalayak. Pemakaian cara-cara menipu menyiratkan adanya kepentingan dan keuntungan tertentu. Sejauh ini hoax berhasil memainkan peran menipu untuk memperdaya khalayak. Dari tipuan yang bersifat elektronis sampai kepada tipuan yang bersifat politis telah berhasil memanfaatkan hoax sebagai media utamanya.

Keenam, mempertimbangkan secara etis sensitivitas keragaman budaya (multikulturalisme). ${ }^{57}$ Konsep sensitivitas budaya termasuk di dalamnya, antara lain: keragaman bahasa dan tafsir atas bahasa; sensitivitas terhadap pandangan masyarakat minoritas; preferensi jender yang berbeda; penghargaan atas kelompok yang diperlakukan khusus dalam masyarakat, misalnya orang-orang cacat atau orangorang dengan HIV/AIDS; dan penghargaan atas perbedaan ras dan suku dalam masyarakat.

Masyarakat digital yang sering kali menyebut dirinya sebagai homo digitalis ${ }^{58}$, seharusnya menjadikan patokan-patokan normatif ini, tidak saja untuk membuat pesan media sosial, tetapi juga menerima dan mencernakan setiap pesan yang tersaji lewat media-media sosial.

Hoax dalam bermedia selalu berakar pada lemahnya sensitivitas, bahkan ketidakpedulian pada aturan norma hukum; akurasi tidak lagi dianggap penting untuk menguji pesan; pengabaian hak istimewa seseorang atas nama kepentingan tertentu; pencampuran ruang privat dan publik tanpa memedulikan batas dari keduanya; niat untuk membohongi/menipu karena kendaraan yang dipakai adalah motif-motif instan, sejenis kekuasaan (politik), ekonomi dan stabilitas dari ideologi tertentu; dan yang paling mengkuatirkan adalah

\footnotetext{
${ }^{57}$ Ibid. Hal., 321-333.

${ }^{58}$ Meminjam istilah Rafael Capurro, F. Budi Hardiman menyebut istilah homo digitalis tidak sekadar gambaran manusia di era komunikasi digital, atau para pengguna gawai, tetapi proses dimana seluruh eksistensi manusia ditentukan oleh tindakantindakan digital, seperti: upload, chatting, posting, dll.
} 
memudarnya sebuah kesadaran akan sensitifnya keragaman dalam sebuah masyarakat pluralistik, seperti Indonesia.

\section{SIMPULAN}

Fenomena hoax sulit dihindari karena ia lahir bersama dengan keterbukaan informasi. Bahkan, dia bisa dianggap sebagai anak kandung keterbukaan itu sendiri. Namun, apakah dengan demikian kita menjadi begitu pasrah dan tidak bisa berbuat sesuatu mengatasi sebuah fenomena over information surplus ini?

Dampak hoax terlalu berisiko, apalagi kalau dibiarkan. Dia tidak saja merusak manusia pada level individual, tetapi dia juga berdampak pada rusaknya tatanan sosial masyarakat, bahkan negara dengan segala kompleksitas keragaman yang dimiliki.

Dari seluruh pembahasan di atas dapat kita simpulkan bahwa hoax hanya bisa diatasi dengan dua perangkat modal sosial, yaitu modal formal konstitusional dan modal modal etis normatif sebagai warisan nilai luhur bangsa.

Dengan modal formal konstitusional kita memiliki seperangkat aturan undang-undang untuk membatasi kerusakan akibat pemanfaatan media sosial yang tanpa batas. Penegakan aturan tetap menjadi penting, karena dia menjadi alat bagi negara untuk memastikan kenyamanan, keamanan, dan keutuhan bernegara dalam bingkai Negara Kesatuan Republik Indonesia (NKRI).

$$
\text { Negara harus mampu }
$$

mengendalikan tendensi destruktif media sosial, tidak sebaliknya media sosial mengendalikan negara. Alat yang dimiliki negara adalah aturan perundangan. Sekarang tegakan aturan perundangan yang ada secara konsisten.

Selain modal konstitusional kita juga memiliki modal sejarah, yaitu nilai luhur bangsa yang dapat hidup rukun dalam berbagai perbedaan. Kerukunan hanya bisa dibangun dengan cara memahami dan menerima perbedaan sebagai keniscayaan sejarah.

Pluralitas sejarah bangsa ini ada jauh sebelum perkembangan media sosial sosial sekarang ini. Pelaku media sosial seharusnya membekali diri dengan kesadaran etis bahwa penggunaan media sosial yang salah akan merusak keharmonisan dan keutuhan masyarakat.

Prinsip-prinsip etis bermedia, seperti: Kepatuhan kepada norma hukum; Memastikan sebuah kebenaran pesan sebelum disiarkan kepada publik; Menjaga hak istimewa yang melekat pada setiap individu; Memisahkan dengan tegas ranah persoalan privat dari persoalan publik; Mengungkapkan pesan bermotif bohong fitnah, dan menyerang pribadi seseorang; dan kesadaran penuh bahwa keragaman budaya masyarakat adalah sensitif, harus dianggap sebagai pedoman etis hidup bersama sebagai bangsa.

\section{DAFTAR PUSTAKA}

Bertens, K. 2013. Etika (Revisi). Yogyakarta: Kanisius.

Echols, John dan Hassan Shadily. 2000. Kamus Inggris-Indonesia, An English-Indonesian Dictionary. Jakarta: Gramedia.

Departemen Pendidikan Nasional. 2008. Kamus Besar Bahasa Indonesia (Edisi ke-4). Jakarta: Gramedia.

Dokumentasi Undang-undang Ketentuan Pokok Pers No. 11 Tahun 1966.

Dokumentasi Undang-undang Ketentuan Pokok Pers No. 21 Tahun 1982.

Dokumentasi Undang-undang Pers No. 40 Tahun 1999.

Dokumentasi Undang-undang Pers No. 11 Tahun 2008.

George, John. 1994. Lies, Credulity, Ignorance, and More Lies. dalam Jurnal Council for Democratic \& Secular Humanism Summer.

Hardiman, F. Budi. 2017. Keadilan dan Keadaban dalam Perspektif Filsafat dan Ajaran Sosial Gereja. Materi Seminar. Jakarta. 
Hardiman, F. Budi. 2018. Homo Digitalis: Kondisi Manusia di Era Komunikasi Digital. Materi Seminar. Jakarta: STF Driyarkara.

Kementerian Komunikasi \& Informatika. 2018. Laporan Tahunan Kementerian Komunikasi \& Informatika Tahun 2017. Jakarta.

Mulyana, Deddy. 2013. Metodologi Penelitian Kualitatif. Paradigma Baru Ilmu Komunikasi dan Ilmu Sosial lainnya. Bandung: Rosda Karya.

Nugroho, Septiaji Eko. 2017. Upaya Masyarakat Anti Fitnah Indonesia Mengembalikan Jatidiri Bangsa dengan Gerakan Anti Hoax. Prosiding pada Konferensi Nasional Peneliti Muda Psikologi Indonesia, Vol. 2, No. 1.

Rich, Carole. 2010. Writing and Reporting News. A. Coaching Method. Boston: Wadsworth USA.

Salim, Peter. 1996. The Contemporary English-Indonesian Dictionary. Jakarta: Modern English Press.
Salvi, Maurizio. 2012. Ethics of Information and Communication Technologies. Luxemberg: European Commission.

Sudarminta, J. 2013. Etika Umum. Kajian tentang Beberapa Masalah Pokok dan Teori Etika Normatif. Yogyakarta: Kanisius.

Suseno, Franz Magnis. 1987 (cetakan 15, 2017). Etika Dasar. MasalahMasalah Pokok Filsafat Moral. Yogyakarta: Kanisius.

Watson, James dan Anne Hill. 2012. Dictionary of Media Studies (8th Edition). New York: Bloomsbury Puslishing.

William, Louise and Roland Rich (ed.). 2013. Losing Control: Freedom of the Press in Asia. Canberra: Australian National University Press.

Wimmer, Roger D. Dan Joseph R. Dominick. 2011. Mass Media Research, An Introduction (Ninth Edition). Boston: Wardsworth Cengage Learning. 